\title{
The Impact of Reflective Practices of English Language Teachers on the Development of A Sense of Agency
}

\author{
Birsen Tutunis $^{1}$, Ozge Hacifazlioglu ${ }^{1}$ \\ ${ }^{1}$ İstanbul Kultur University, Faculty of Education \\ Correspondence: Birsen Tutunis, İstanbul Kultur University, Faculty of Education, Turkey.
}

Received: July 4, $2018 \quad$ Accepted: July 23, $2018 \quad$ Online Published: August 20, 2018

doi:10.11114/jets.v6i10.3409 URL: https://doi.org/10.11114/jets.v6i10.3409

\begin{abstract}
Language teaching has undergone many changes for several decades and is still changing within this complex dynamic system. Teaching is recognized as both individually practised and socially shaped phenomenon with lots of constraints imposed by the society. The concept of agency has been theorized from an interdisciplinary approach incorporating academic disciplines of sociology, philosophy, anthropology, management, economics and the related fields. The aim of this paper is to address this gap in the literature by examining the experiences of language teachers working with young learners. There is limited research literature that specifically addresses the practices of teacher agencies in language teaching. However, Johnson (2009) for example, based on Vygotsky's (1958) sociocultural theory, suggests to take a sociocultural approach in teacher education to acknowledge both social forces and the individual experiences that shape language teaching. A qualitative pilot study was conducted with 30 language teachers working in disadvantaged neighborhoods in İstanbul, Turkey with the purpose of finding out their reflective practices on the development of a sense of agency. The data was analyzed and interpreted from the basis of "professionalism and teacher identity" and provisional insights are provided for policy makers, teachers, administrators and leaders at various levels in schools and faculties of education that we believe will contribute to the literature on teacher agencies and professionalization in the field of second/foreign language teaching.
\end{abstract}

Keywrds: teaching english to young learners, english as a foreign/second language, teacher agency, reflective practices

\section{Introduction}

Language teaching has undergone many changes for several decades and is still changing within this complex dynamic system. Teaching is recognized as both individually practised and socially shaped phenomenon with lots of constraints imposed by the society. The concept of agency has been theorized from an interdisciplinary approach incorporating academic disciplines of sociology, philosophy, anthropology, management, economics and the related fields. To assist teachers in their struggle to adapt themselves to the changes, Johnson (2009), based on Vygotsky's sociocultural theory, suggests to take a sociocultural approach in teacher education to acknowledge both social forces and the individual experiences that shape language teaching.

Foreign language teacher agency is relatively a new concept and mostly examined from the lenses of "teacher professionalization" and "teacher identity". The extant literature on language teachers focuses mostly on their training needs, however only a few studies address how language teachers become more professionalized in their work through creating agencies.

Vygotsky's sociocultural theory of human learning describes learning as a social process and the origination of the human intelligence in society and culture. The theoretical framework is that social interaction plays a fundamental role in the development of cognition. Vygotsky believed everything is learned on two levels: First through interaction with others, and then integrated into the individual's mental structure saying" all higher functions originate as actual relationship between individuals" (Vygotsky 1958). Argyris (1993) also asserts that "double-loop learning in a community of practice" enables professionals to reflect upon their performances and take actions while making a change in their professional careers. We found limited research literature that specifically addresses the practices of teacher agencies in language teaching but we infer from the aforementioned studies and our current study that communities of practice may promote professional development when teachers, scholars and practitioners work 
together. The findings of this study are expected to open a platform for discussion to develop alternative methods to enhance the practice of teachers' agencies in language teaching.

The aim of this study is to address this gap in the literature by examining the experiences of language teachers working with young learners. This study presents the findings of a qualitative study conducted with 30 language teachers working in disadvantaged neighborhoods in İstanbul, Turkey. First, we review the literature on teacher agencies and professionalism through the prism of reflective practice and communities of practice. Then we analyze and interpret the interview data from the basis of "professionalism and teacher identity". Finally, we provide provisional insights for policy makers, teachers, administrators and leaders at various levels in schools and faculties of education and contribute to the literature on teacher agencies and professionalization in the field of second/foreign language teaching.

\subsection{Practice, Communities of Practice and Foreign Language Teacher Agency}

Teacher cognition research is concerned with understanding what teachers think, know and believe- the unobservable dimension of teaching-teachers mental lives. Phipps and Borg (2007) summarize the nature of teacher cognition and its relationship to what teachers do in several items. They believe teachers' cognition can be influenced by their experiences as learners and they can be deep rooted and resistant. Language teachers' cognition has been an established field of study now and the most researched area has been language grammar teaching. Such research has developed our understanding of the way teachers teach grammar and of their thinking behind their practices.

Another researched area is learner autonomy but teacher autonomy seems to be neglected. Toohey (2007) conceptualizes teacher autonomy in relation to agency, emphasizing that teachers are agentive and that their agency is mediated by the sociocultural contexts of their teaching. Thus, teachers' actions and their thinking behind their practices need to be studied in detail to find out the deep - rooted thoughts that influence their self- initiated actions, their agency development. In order to fully analyze the notion of foreign language teacher agency, we need to focus on the notion of professionalism and teacher identity.

Professionalization could be defined as "the process of using education and certification to enhance the quality of performance of those within an occupational field" (Shanahan, Meehan, \& Mogge, 1994, p. 3). Millerson (1964), Merriam (2001) came up with some lists to explain the difference of professions from occupations. These lists include education and training, the competence of professionals ensured by examinations, a code of conduct to ensure professional integrity, performance of a service that is for the public good, and a professional association that organizes members, to be full time occupation, to be respected by society, development in literature and graduate studies. In this context, "Communities of Practice" is defined as a voluntary transformational learning process where the participants are provided opportunities to reflect upon, reify and transform their identities as teachers-leaders in the profession. In language teachers' professional development paths, this type of transformational learning pursues with purposeful interaction, collaboration, and participation with others in a community of practice (Wenger, 1998).

"Communities of practice" and "reflective practice" constitute the main pillars of teacher professionalism. The notion of learning through authentic conversations could be transferred to the teachers, through which they learn different stories and take lessons for their own learning. This projects the notion of "professional learning communities", which was also examined by Kruse and Seashore (2007) as a major lever for improving teachers' work lives. As Portner indicated "mentoring requires interaction and mentor-mentee interactions should take place within a relationship that includes trust, honesty, respect and joyful willingness" (2003, p. 11). Mentors build and maintain relationships with their mentees based on mutual trust, respect, and professionalism. Relating behaviors create an environment that allows mentors develop a genuine understanding of their mentees' ideas and needs and encourages mentees to honestly share and reflect upon their experiences. In their study, Young, Alvermann, Kaste, Henderson, and Mnay noted that "interdependency encouraged individual growth while simultaneously facilitating a sense of friendship collegiality connectedness and caring between mentors and mentees" (2004, p. 23). As it was emphasized by Feiman-Nemser, effective mentoring practice allows the new teacher to "construct his or her own professional knowledge" (2001, p. 20); (cited in Bakioglu, Hacifazlioglu and Ozcan, 2010).

Mentoring aligns with the idea of reflection, which in a way shapes teachers' perceptions of professionalism, eventually leading paths for creating teacher agencies. The concepts underlying reflective practice dates back to 1900s, when reflective practice was seen as way of exploring indiviual and collective experiences through interaction and reflection. In 1980s Schön introduced the idea of "Reflective Practice" in order to explain how professionals meet the challenges of their work with a professional manner through improving practices. Reflective practices were categorized as follows (Schön, 1987):

\section{- Self Reflection \\ - Peer Reflection}


- Group Reflection

- School-wide Reflection

Each category is critically important in teachers' careers. Categories could be practiced seperately as well as combining them through alternative strategies. In these processes, teachers play the role of a mentor or a mentee by taking turns. Furlong and Maynard (1995) note that as a co-enquirer, mentors and mentees interact and shoulder responsibilities for their own learning. Hargreaves (2002) present relationship, which is based on professionalism underlying the fact that mentors or mentees in a reflective practice feel distressed at times while making a contribution in one's professional development. Therefore professional dialogues could be seen as "ripples creating waves for learning". These dialogues should be based on mutual trust and sincerity as it was stated by Bakioglu, Hacifazlioglu and Ozcan (2010) on their study on school principals.

There are various ways to create a sustainable and trustable reflective practices. Professional and authentic conversations are to be the most commonly accepted form among these. Clark (2001) notes that authentic dialogues enable us to articulate our own experiences, implicit hopes and fears in the intellectual and emotional company of others whom we trust (p. 177). Our study is based on the assumption that when teachers engage in social practice with others, they gain new understandings of the practice and ways of being in the practice. Through active interaction and cooperation, teachers develop a sense of belonging to the practice and learn new ways to collaborate and reifying their identities as learners and practitioners (Wenger, 1998; Wenger et al. 2002; Hacifazlioglu et al 2017). In this respect reflective practice, communities of practice and other socially constructed professional development practices could serve as "means for teacher professionalism".

\subsection{Purpose}

The present study focuses on a group of teachers who participated in a "Reflective Practice Training Model". It seeks to examine their developing professional identity, in the context of the unique training they received. Therefore the purpose of the study is to examine how Young Learners' English Teachers respond to the challenges they encounter in their profession and the ways in which sub identities of «teacher-self as an instructor» and «a teacher-self as a reflective practitioner» interplay. The research questions for this study are as follows:

\section{Research Questions}

Research Question 1: What are the initial challenges encountered by the English teachers in the first two years of their teaching to young learners in disadvantaged neighborhoods?

Research Question 2: How do English teachers overcome the initial challenges?

Research Question 3: What are the reflection experiences of English teachers before and after training?

\section{Methodology (Integrative Case Design)}

The research was conducted as a case study among qualitative reseach methods. "The integrative single case design" is appropriate for specific, exceptional, excessive/marginal situation and the situations away from general standards (Yildirim and Simsek, 2016). This study implements quantitative and qualitative approaches conducted with language teachers working with young learners in İstanbul, Turkey. Since the purpose of the study is to understand the perspectives of the language teachers, conducting interviews is considered to be the most appropriate data collection as it allows us to obtain more in-depth and detailed information (Creswell, 2014). Researchers used following evidentiary sources from the cases they gave trainings and interacted: "Questionnaires, focus group discussions, interviews and direct observations" (Yin, 2002, p. 96)

\subsection{Participants}

The city of Istanbul in Turkey also has a very large and diverse population. 30 participants from Istanbul constituted the voices of teachers in the study. We used purposeful sampling and exceptional case sampling to choose the schools, based on the criteria of being a language teacher at a primary school or pre-school (kindergarden) in İstanbul. The schools were chosen by Governship of Istanbul and local ministries of education. All were volunteers. Specific information regarding the individuals and their school profiles is not provided to ensure the participants' privacy. 
Table 1. Demographic Profile of the Participants

\begin{tabular}{|c|c|c|}
\hline Gender & $\mathrm{N}$ & $\%$ \\
\hline Male & 6 & 20 \\
\hline Female & 24 & 80 \\
\hline Total & 30 & 100 \\
\hline \multicolumn{3}{|c|}{ Age Group (Years) } \\
\hline $20-30$ & 14 & 46.70 \\
\hline $31-40$ & 13 & 43.30 \\
\hline $41-50$ & 2 & 6.70 \\
\hline Above 51 & 1 & 3.30 \\
\hline Total & 30 & 100 \\
\hline \multicolumn{3}{|c|}{ School Type } \\
\hline Public & 30 & 100 \\
\hline Private & 0 & 0 \\
\hline Total & 30 & 100 \\
\hline \multicolumn{3}{|c|}{ Seniority (Years) } \\
\hline $1-5$ & 11 & 36.70 \\
\hline $6-10$ & 6 & 20 \\
\hline $11-15$ & 7 & 23.30 \\
\hline Above 16 & 6 & 20 \\
\hline Total & 30 & 100 \\
\hline
\end{tabular}

As could be seen in Table 1, majority of the teachers were female. Half of them were within the range of 20-30 years, 43 per cent 31-40 years. Only 10 per cent were above 40 years. 36 per cent have $1-5$ years of experience, 20 per cent 6-10 years, 23 per cent 11-15 years and 20 per cent have 16 and above years of experience. All of the teachers work at public schools located in disadvantaged neighborhoods.

\subsection{Procedure}

This study is based on the following case study steps by using (Yildirim and Simsek, 2016) as a reference (1) developing research questions, (2) developing research sub-problem, (3) determining analysis unit, (4) determining the case, (5) selecting the participants, (6) collecting data and making connection with the sub-problem, (7) data analysis and interpretation and (8) reporting the case study. The project was practice-oriented, whereby faculty members from the fields of teacher education, English language teaching and early childhood education offered trainings for young learners English teachers. The project consists of trainings that incorporate the notion of reflective practice and alternative teaching methods from an interdisciplinary perspective. Phases of the project are indicated below.

\section{Phases of the Teacher Reflection Project}

Phase 1: In collaboration with the Faculty of Education, the director of English Preparatory Program sent a letter to the Educational Directorate of Istanbul Province asking for permission to conduct the project on young learners English teachers working in disadvantaged neighborhoods. Researchers assured the Ministry that all the rights of teachers involved in the project would be carefully protected.

Phase 2 Development of Training Sessions: The training model is based on "Mentorship and Communities of Experience" by using Vygotsky (1978), Clark (2001), Wenger (2002; 2008), as references. Trainings were tailored in a way to reveal recent trends in language teaching while creating a platform for a professional learning whereby teachers and faculty members (trainers) could learn through academic and social interaction.

Phase 3: The project was conducted in June 2016 and lasted for one week. Seminar and training sessions were held at a meeting room at the university allocated only for the purpose of the project. As the active participants of the projects researchers both organized the project and gave the trainings while collecting quantitative and qualitative data. 
Phase 4: Simultaneously with trainings, teachers' perceptions were collected via a questionnaire. Researchers also held focus group discussions each day asking them to reflect upon their experiences.

Phase 5: After the project, researchers kept on their interaction with the teachers and provided informal mentoring support.

The study was based on both quantitative and qualitative stance. Researchers used questionnaires and focus group discussions to reveal the ways in which teachers' developed a sense of agency through reflective practice based on the trainings given in a collaborative manner. It should be noted that this project aims to give a perspective of how an awareness could be created in terms of professional identity.

\subsection{Questionnaires}

The quantitative part has two phases. The first phase was the development of the draft instrumentation phase and in that phase the "English Language Teachers' Mentoring and Reflective Practice Experiences Questionnaire' was developed and administered to 10 language teachers as a pilot study. Feedback from the teachers and the experts have been obtained. As a result the questionnaire was given its final form, which was conducted on 30 teachers on the first day of the Project. The questionnaire was also administered to the same group of teachers at the end of the project. Therefore researchers expected to see the change in teachers' perceptions after a weeklong training sessions.

\subsection{Interviews}

Focus group discussions were held during an in-service training program by the participants. Questionnaires were administered in June 2016 during in-service training course provided for foreign language teachers. Focus groups were held with a more limited number of teachers in a more intense form. Those were held in five sessions, each lasting approximately one hour with five groups of 6 teachers with the total number of 30. Initially, we gave a session about mentoring and reflective practice to the participants who attended each session and asked them to report their own reflective practice and mentoring experiences. Participants were reassured that their identities would remain confidential. Therefore no real names were listed on any documents or data related to this research. As we interviewed teachers, we used reflective listening, remaining open and non-judgmental in the process.

\subsection{Observations}

Researchers had the opportunity to visit schools located in disadvantaged neighborhoods and be constantly interaction with the language teachers working in those schools and reported their observations notes. Focus group discussion and reflections written in questionnaires were used as the primary source of data while observation notes were only used when there is a need to find explanation. Therefore it should be noted that researchers did not use observation notes as a source of data for the analysis.

\subsection{Data Analysis}

Quantitative Data: In the analysis of quantitative data, SPSS (Statistical Package for Social Sciences) was used. We coded each questionnaire. Of the 33 questionnaires administered 30 were returned. The rate of return was high since questionnaires were administered during in-service training courses.

Qualitative Data Analysis: We divided the analysis procedure into the five parts as suggested by Marshall and Rossman (1999): a) organizing data; b) identifying themes, patterns, and categories; c) testing the emergent hypothesis against the data; d) searching for alternative explanations of the data; and e) writing the report. We then selected excerpts from the transcripts and placed them into broad categories in search of thematic connections within and among the transcripts (Seidman, 1998). Our next step was to develop narrative summaries, which Maxwell (1996) describes as thumbnail sketches that capture a few pertinent high lights from an insider's perspective. Throughout the analysis process, we used teachers' own voices and words to describe their experiences (cited in Hacifazlioglu, 2010).

\section{Findings: Reflections of Language Teachers}

Responses given to the questionnaires and reflections shared during focus group discussions revealed three main themes which are: "Journey of Teacher Professionalism Encountered with Road Blocks, Building Agency within The School and across The School and Journey of Reflective Practice And Creating a Professional Identity as a Young Learners English Teacher". The themes and the sub themes will be interpreted from the prism of foreign language teacher agency. Anecdotes and excerpts taken from the interviews will be shared in this section. 
Table 2. Themes and Sub Themes: Development of Self Agency and Young Learners English Teacher Identity

- $\quad$ Theme 1: Journey of teacher professionalism encountered with road blocks

Sub Theme 1.1: Initial Challenges Encountered in the First Two Years

Sub Theme 1.2: Being a Creative Young Learners English Teacher in a Disadvantaged Neighborhood

- $\quad$ Theme 2: Building Agency within the School and Across the School

- $\quad$ Theme 3: Journey of reflective practice and Creating a professional identity as a Young Learners English Teacher

Sub Theme 2. 1: The interplay of reflection types in construction of teacher professionalism

Sub Theme 2. 2: The interplay of sub identities as a teacher, a mentor and a mentee

Theme 1: Journey of teacher professionalism encountered with road blocks (Research Question)

In line with the first research question teachers were asked what sorts of initial challenges they encountered in the first two years of their teaching to young learners in disadvantaged neighborhoods.

\subsection{Sub Theme 1.1.: Initial Challenges Encountered in the First Two Years}

This theme falls into two sub themes of "Initial Challenges Encountered in the First Two Years" and "Being a Creative Young Learners English Teacher in a Disadvantaged Neighborhood". Initial challenges encountered by the participants are stated as; negative conditions related to children like the whole family (5-10 family members) living in one room, children working after school, health problems, and uneducated parents. Such negative conditions caused lack of communication with parents and less interaction with students.

Families appeared to favor classroom teacher more than the English teacher because they did not consider English as an important subject to be studied, rather as a lesson where students are kept in class playing games and singing songs. One of the participant teachers shared an anecdote with us: "One day I saw a woman with a 4 year old child waiting in front of my class. When I asked, she said she did not have anybody to take care of the child at home and she had to do some shopping. She asked whether she could leave the child with her sister in my class". Creating a learning culture within the classroom with the help of families- was difficult.

Table 3. Challenges Encountered in Professional Development

\begin{tabular}{lccccccc}
\hline & \multicolumn{2}{c}{ Yes } & \multicolumn{2}{c}{ No } & \multicolumn{2}{c}{ Total } \\
& $\mathrm{N}$ & $\%$ & $\mathrm{n}$ & $\%$ & $\mathrm{~N}$ & $\%$ \\
\hline Low motivation & 20 & 66.7 & 10 & 33.3 & 30 & 100 \\
Hard working conditions & 10 & 33.3 & 20 & 66.7 & 30 & 100 \\
Family responsibilities and family problems & 27 & 90 & 3 & 10 & 30 & 100 \\
Negative conditions related to children & 30 & 100 & 0 & 0 & 30 & 100 \\
Financial constraints & 21 & 70 & 9 & 30 & 30 & 100 \\
Health problems & 27 & 90 & 3 & 10 & 30 & 100 \\
Other & 26 & 86.7 & 4 & 13.3 & 30 & 100 \\
\hline
\end{tabular}

3.2 Sub Theme 1.2.: Being a Creative Young Learners English Teacher in a Disadvantaged Neighborhood

One of the training course component was creativity. The teachers wrote their own stories, made puppets and story books and enjoyed being creative. However, being a creative English teacher in a disadvantaged neighborhood is considered to be rather difficult because of the working conditions. The problems are stated as follows:

- $\quad$ Teaching young learners is different from teaching teen- agers or adults.

- $\quad$ The teaching materials are not provided.

- There is little support from the administration.

- Ministry of Education sets the syllabus and decides on the book but does not do in-service training.

- $\quad$ There is no time for creativity. Teachers teach 25-30 contact hours per week. 
Most of the teachers indicated familial and personal problems that serve as a road block for their professional development. Teachers showed the influence of the profile of students and their families as one of the reasons that hinder their professional development. It was revealed during the conversations that the mentality of families and their perspectives of what language teaching is and what the responsibilities of a language teacher are has a negative effect on the classroom setting. This puts a burden on the shoulders of the language teachers, which is reflected on professional development activities in a negative way. Teachers also indicated family problems and responsibilities as a family as factors that serves as a barrier to participate in professional development activities. As well they also noted having financial constraints as one of the limitations that stop them from being actively involved in professional development activities such as trainings, seminars and conferences. That is why they were happy to be a part of the project and be an active member of the learning community that is aimed to be created.

\subsection{Theme 2: Building Agency within the School and Across the School (Research Question 2)}

Teachers' beliefs and actions are interrelated. Being an active English teacher means being an active agent in and off one's work. Agency is something that people do; not what they possess. English teachers teaching young learners possess the necessary knowledge and skills but they are not active agents due to the challenges they face.

ELT teachers teaching for young learners were asked the extent to which they feel satisfied with the professional development opportunities they have. 53 per cent noted that they are satisfied with their current conditions while 47 of them are unhappy with the lack of opportunities for professional growth. They were also asked what sorts of professional development activities they participate. Out of 30 teachers only 1 of them indicated that enrollment in a graduate program enables them to be constantly in relation with the recent developments. Majority of the teachers noted reading books and journals as one of the most common means to keep updated with the recent developments of the field. 6 of them indicated participation to online courses and continuous education seminars. None of them mentioned mentoring as one of the ways that could cultivate their professional development as a teacher. It should also be noted that they are eager to share the best practices with their colleagues as a part of professional development. 20 of the teachers (90 per cent) underlined the importance of sharing best practices and co-teaching as a means for professional growth. Half of the teachers (50 per cent) indicated that they provide assistance and support in the form of mentoring while 40 per cent hardly ever get involved in such a support system at the beginning of the project. 10 per cent of the teachers emphasized the ways in which mentoring opens paths for professional development. During the focus group discussion they gave hints about the ways how they created informal support systems with their colleagues without being aware of the name given in the related scholarship. This issue also came up during the trainings and focus group discussions and teachers noted that they were not aware of the intellectual value of the gathering and sharing sessions they have with their colleagues. As it could be seen in the remaining parts of the article they will become aware of the models they have been involved in without having a clue of how they could be related with theory.

\subsection{Theme 3: Journey of Reflective Practice and Creating a Professional Identity as an English Teacher (Research} Question 3)

Identities are not fixed and change over time.Student teachers change their student identity in the last year of their university education to teacher identity and try to adapt themselves to the new conditions. The participants of this study expressed how difficult it was to reconstruct their identities according to the social and cultural factors of the specific context (Disadvantaged Neighborhood) they worked.Transitioning from studentship to teaching was not as easy as imagined. They stated how disillusioned they were at the beginning. They were ready and enthusiastic to teaching English but the school directors seemed to ignore them. One of the teachers said: „, I was expecting to be invited to the staff meeting but I was not and I felt unimportant. I was the only English teacher to teach all grades but no one bothered to ask me how I was doing “.

Another participant teacher stated that she was not the only English teacher but she did not collaborate with the other teacher. She said: ,, If I wanted to share my classroom experiences, I would do it with my colleague in another school“. There was no reflective practice. Teachers were given a week long self- reflection training. Table 4 below shows the ways in which training had an influence on their perceptions towards implementing reflective practice in their own professional experiences. 
Table 4. Perceptions of Teachers Before and After the Trainings

\begin{tabular}{cccccccc}
\hline & \multicolumn{2}{c}{ Never } & \multicolumn{2}{c}{ Sometimes } & \multicolumn{2}{c}{ Often } \\
\hline & before & after & before & After & before & after \\
\hline Self-reflection & $\% 0,00$ & $\% 0,00$ & $\% 43,33$ & $\% 10,26$ & $\% 56,67$ & $\% 89,74$ \\
Peer Reflection & $\% 0,00$ & $\% 0,00$ & $\% 60,00$ & $\% 28,21$ & $\% 40,00$ & $\% 71,79$ \\
Reflection within the department & $\% 10,00$ & $\% 0,00$ & $\% 63,33$ & $\% 15,38$ & $\% 26,67$ & $\% 84,62$ \\
School-wide reflection & $\% 20,00$ & $\% 0,00$ & $\% 70,00$ & $\% 28,21$ & $\% 10,00$ & $\% 71,79$ \\
District-wide reflection & $\% 70,00$ & $\% 10,26$ & $\% 30,00$ & $\% 64,10$ & $\% 0,00$ & $\% 25,64$
\end{tabular}

As for "self-reflection", their tendency was to practice it "sometimes". After the trainings majority of them (89 per cent) noted that they would use self-reflection most of the time in their professional lives. As it was noted by Popper-Giveon and Shayslon (2017) teachers professional identity stands at the core of the teaching profession. And provides a framework of how they could construct their own ideas of how to be a better teacher and how to make a change in the lives of children.

Same results was seen in the case of "peer reflection". During the focus group discussions, teachers noted that they use peer reflection most of the time but the nature of this interaction was limited to one or two people since this is a relationship that is based on "trust and sincerity". They also asserted that they have the tendency to choose and work with colleagues not from the school they currently work but from another school. They expressed the anxiety they when they reveal any professional constraints. Their responses showed that professional identity as an English teacher for young learners is placed in the core of their lives. As it was stated by Flores and Day (2006) their identity shifts over time with the external influences such as job experience and insecure working conditions. Teachers ' responses seem to align with the identity described by Popper-Giveon and Shayslon (2017) as neither being fixed or imposed rather negotiated through experience and the sense a teacher develops. Teachers shared the reflections about the ways how they become aware of their own learning path as teacher, a mentor and a mentee. Being a teaching is a passion and being a teacher and a life-long learner requires one to be a mentee and a mentor throughout his or her own professional career. Their words echoed Garvey and Alfred's (2000) study on teacher mentoring by saying their potentials to teach better and to be better teachers for the young learners is unlocked when there is support, guidance and collaboration (p. 121).

Comparative results showed the change observed in teachers perceptions towards "self -reflection within the department". During the focus group discussions before the training they seem to be sceptical for the reflection created within the department by a group of teachers. They implied tension between two professional sub identities: "Being a language teacher and mentor that supports other novice and experienced colleagues". Within the sub identity of being a language teacher they also reveal concerns for not being a competent teacher for the young learners. This was also seen in the responses they gave to the questionnaire. However the change in the perceptions is evident as it could be seen with a per cent of 84 teachers who wants to be involved in the group self- reflection. This result also aligns with "school wide reflection". Teachers indicated that the project enabled them to be aware of the power and beauty of group and "school wide reflection".

Teachers' perceptions of district wide reflection appears to decrease after the trainings. Before the project they shared stories of training given mandatory by local authorities in a traditional manner. They way how those trainings were imposed in a way kept away from the idea of self- reflection and group reflection instead create a sub identity of a teacher being loyal and obedient to rules and regulations. Therefore the need for professional development was expected to be organized and planned by the authorities. However the way how the current project was proposed them served as a means to create a novel sub identity of a teachers based on "reflective practice". After the project they were aware that the need should come from inside and the synergy created among the teachers could be more powerful than any standard training. No matter how rich format and the content of the training it may not make a change in the lives of teachers unless they are channeled with the most effective means like "communities of practice". 
Table 5. In-service training areas that teachers want to get support

\begin{tabular}{cccccccc}
\hline & \multicolumn{2}{c}{ Yes } & \multicolumn{2}{c}{ No } & \multicolumn{2}{c}{ Total } \\
& $\mathrm{n}$ & $\%$ & $\mathrm{n}$ & $\%$ & $\mathrm{~N}$ & $\%$ \\
\hline Technology & 18 & 60 & 12 & 40 & 30 & 100 \\
Interpersonal relations & 25 & 50 & 15 & 50 & 30 & 100 \\
Communities of practice & 20 & 66.7 & 10 & 33.3 & 30 & 100 \\
Innovative practices in teaching English & 26 & 86.7 & 4 & 13.3 & 30 & 100 \\
Measurement and evaluation & 11 & 36.7 & 19 & 63.3 & 30 & 100 \\
Recognizing the student & 14 & 46.7 & 16 & 53.3 & 30 & 100 \\
Other & 4 & 13.3 & 26 & 86.7 & 30 & 100
\end{tabular}

Teachers were asked what sorts trainings they want to participate after having the one week long intensive training of reflective practice. They noted "innovative practice in teaching English" by saying that they would be eager to continue the start-up training they were provided by intensive workshops. This project gave them an awareness of what sorts of alternative teaching methods could be used and the ways in which this could be challenged to various groups of students whether be in an advantaged or disadvantaged neighborhood. In line with this preference they also underlined the need for cultivating their interpersonal relations. Most of them asserted that they feel the need to be equipped with the necessary communication means to create synergy both with children and the parents. 70 per cent of the teachers highlighted the need to learn how to create communities of practice in their own school settings. In line with this preference it also appeared in the conversations that they would be happy to have an ongoing support mechanism that will enable them to establish such networking and synergy groups within the schools. Their preferences in a way highlighted the need felt for "action research".

\section{Results and Discussion}

Our results seem to align with Bakioglu, Hacifazlioglu and Ozcan's (2010) study on school administrators, in which a channel of mutuality between the career phases of the teachers and the concept of trust in a mentoring relationship appeared. In parallel with Kram's (1983), Huberman's (1989), Bakioglu's (1996), Day and Bakioglu (1996) and Bakioglu, Hacifazlioglu and Ozcan's (2010) study on teachers and school principals, young learners' English teachers in this study also felt less secure in their personal relationships with their mentors in the earlier phases of their careers. That is why trust is indicated as one of the key components in a networking or professional community or a mentoring relationship. All of the teachers in our study underlined the vital role of trust in creating communities of practice. All of the voices seem to echo following words given by Hargreaves (2002): "Trust is a vital ingredient of productive professional collaboration" (p. 394).

\section{References}

Argyris, C. (1993) Knowledge for Action: A guide to overcoming barriers to organizational change, San Francisco: Jossey Bass.

Bakioglu, A. (1996). Professional development of educators, unpublished research. Istanbul: Faculty of Education, Marmara University.

Bakioglu, A., Ozcan, K., \& Hacifazlioglu, O. (2010). Influence of mentors on principals' career phases. Teachers and Teaching: Theory and Practice. 16 (2): 245-258. https://doi.org/10.1080/13540600903478482

Borg, S. (2006). Teacher Cognition and Language Education: Research and Practice, Continuum.

Clark, C. M. (2001). Talking shop. New York: Teachers College Press.

Creswell, J. (2014). A concise introduction to mixed methods research. Lincoln: Sage Pub.

Day, C., \& Bakioglu, A. (1996). Development and disenchantment in the professional lives of head teachers. In I.F. Goodson \& A. Hargreaves (Eds.), Teachers' professional lives (pp. 205-227). London: Falmer Press.

Feiman-Nemser, S. (2001). Helping novices learn to teach: Lessons from an exemplary support teacher. Journal of Teacher Education, 25(1), 17-30. https://doi.org/10.1177/0022487101052001003

Furlong, J., \& Maynard, T. (1995). Mentoring student teachers. New York: Roudledge. 
Garvey, B., \& Alfred, G. (2000). Educating mentors. Mentoring and Tutoring, 8(2), 113-127. https://doi.org/10.1080/713685525

Hargreaves, A. (2002). Teaching and betrayal. Teachers and Teaching: Theory and Practice, 8(3/4), 393-407. https://doi.org/10.1080/135406002100000521

Huberman, M. (1989). The professional life cycle of teachers. Teachers College Record, 91(1), 31-57.

Johnson, K. E. (2009). Second Language Teacher Education: Sociocultural perspective (ESL \& Applied Linguistics Professional Series), NY Routledge

Kruse, S. G., \& Seashore, L. K. (2007). Developing collective understanding over time: Reflections on building professional community. In L. Stoll \& K.L. Seashore (Eds.), Professional learning communities: Divergence, detail, difficulties (pp. 129-149). Buckingham: Open University Press.

Marshall, C., \& Rossman, G. R. (1999). Designing qualitative research, 3rd edn. Newbury Park, CA: SAGE Publications.

Merriam, S. B. (2001). The new update on adult learning theory. San Francisco: Jossey-Bass.

Millerson, G. (1964). The Qualifying Association. London: Routledge \& Kegan Paul.

Phipps, S., \& Borg, S. (2007). Exploring the relationships between teachers' beliefs and their classroom practice, The teacher Trainer, 21(3), 17-19

Phipps, S., \& Borg, S. (2009). Exploring tensions between teachers' grammar teaching beliefs and practices, System, 37, 380-390. https://doi.org/10.1016/j.system.2009.03.002

Portner, H. (2003). Mentoring New Teachers, U.S: SAGE Publications.

Schön, D. A. (1987). Educating the reflective practicioner. San Francisco: Jossey-Bass.

Shanahan, T. Meehan, M., \& Mogge, S. (1994). The Professionalization of the Teacher in Adult Literacy Education, University of Illinois at Chicago Center for Literacy NCAL Technical Report Tr 94-11, 3

Toohey, K. (2007). Conclusion: Autonomy/agency through sociocultural lenses. In A. Barfield and S. Brown (eds.) Re-interpreting autonomy in language education (pp. 231-242). London: Palgrave-Macmillan.

Vygotsky, L. (1978). Mind in Society: The development of higher psychological processes Cambridge, MA: Harvard University Press

Wenger, E. (1998). Communities of practice: learning, meaning, and identity. Cambridge University Press. https://doi.org/10.1017/CBO9780511803932

Wenger, E., McDermott, R., \& Snyder, W. M. (2002). Cultivating communities of practice. Boston, MA: Harvard Business School Press.

Yıldırım, A., \& Simşek, H. (2013). Sosyal bilimlerde nitel arastırma yontemleri. Ankara: Seçkin Yayınları.

Yin, R. K. (2002). Case study research: Design and methods. Thousand Oaks, CA: SAGE Publications.

Young, J. P., Alvermann, D., Kaste, J., Henderson, S., \& Mnay, J. (2004). Being a friend and a mentor at the same time: A pooled case comparison. Mentoring and Tutoring, 12(1), 23-26. https://doi.org/10.1080/1361126042000183066

\section{Copyrights}

Copyright for this article is retained by the author(s), with first publication rights granted to the journal.

This is an open-access article distributed under the terms and conditions of the Creative Commons Attribution license which permits unrestricted use, distribution, and reproduction in any medium, provided the original work is properly cited. 